\title{
Impact of Capital Flight on Economic Growth in Nigeria: An Econometric Approach
}

\author{
Samson Bredino ${ }^{1}$, Peter Fiderikumo ${ }^{2}$, Adedoyin Adesuji ${ }^{3}$ \\ ${ }^{1}$ Economics Department, University of Port Harcourt, Rivers State, Nigeria \\ ${ }^{2}$ Department of Banking and Finance, Bayelsa State College of Arts and Science, Bayelsa State, Nigeria \\ ${ }^{3}$ Petroleum and Gas Engineering Department, University of Port-Harcourt, Rivers State, Nigeria
}

Email address:

sbredino@yahoo.com (S. Bredino)

\section{To cite this article:}

Samson Bredino, Peter Fiderikumo, Adedoyin Adesuji. Impact of Capital Flight on Economic Growth in Nigeria: An Econometric Approach. Journal of Business and Economic Development. Vol. 3, No. 1, 2018, pp. 22-29. doi: 10.11648/j.jbed.20180301.14

Received: December 22, 2017; Accepted: January 15, 2018; Published: March 21, 2018

\begin{abstract}
This article examined the impact of capital flight on economic growth in Nigeria. Classical methods of predicting impact of capital flight on economic growth have not yielded much result. This research examines time series data which includes gross domestic product (GDP), capital flight, exchange rate and external debt which was computed from the national Bureau of Statistics and central Bank of Nigeria Statistical Bulletin. The model estimated to cover the period $1980-2012$ was analyzed using combined global technique, Artificial Neural Network (ANN) as a predictive technique and classical techniques like Ordinary Least Square (OLS) and co-integration/error correction methods. The variable in the model was estimated for possible co-integration. Research finding showed that capital flight have adverse impact on the GDP, while exchange rate impacts positively on the GDP which is in consonance with apriori expectation. Based on the findings, recommendations were made on how to check the menace of capital flight in Nigeria. Among such recommendation is the need for the government to setup appropriate institutions to check the volume of capital that is been flown out of the country, there should be restrictions on external borrowing tendencies on all levels of governments and agencies as well as private sector organizations; government should maintain a competitive and stable exchange rate policy.
\end{abstract}

Keywords: Gross Domestic Product, Capital Flight, External Debt, Exchange Rate

\section{Introduction}

Capital flight whether normal or abnormal has a damaging effect on the economy of the source or domestic country [1]. Capital flight affects negatively and significantly domestic investment. The implication being that the movement of capital abroad leaves little or less resources for financing domestic investment [2].

It is generally acknowledged that shortage of funds to finance economic development is a major challenge confronting African continent. Thus encouraging continuous operation and inflow of foreign capital by the way of foreign investment cannot be over emphasized in order to bridge the existing resource gap in the third world countries. Many developing countries have resorted to external borrowing as a way of bridging their saving-investment gap. It is indeed a paradox, however, that while the countries are suffering from inadequate resources, huge amount of funds are being siphoned abroad by wealthy residents and political officeholders of these debtor countries.

Nigeria for instance, with the rate of almost $\$ 10$ billion annual loss to capital flight is the leader in the league of African countries suffering from this menace. Others are Egypt, Algeria, Morocco and South Africa. Capital flight, if successfully reversed would not only relieve the economy of the burden but leave more resources for poverty alleviation.

Consequent upon the aforementioned, this study is an attempt to ascertain the impact capital flight, exchange rate and external debt have on economic growth.

Review of Literature

According to cooper and Hardt (2000), capital flight entails flow of financial assets resulting from the holder's perception that capital is subjected to inordinate level of risk due to devaluation, hyperinflation, political turmoil or expropriation of retained earnings at home in domestic currencies [3]. The owner of funds in this hostile 
environment is seeking a safe haven for his funds. Boyce, J. K., \& Ndukumana, L. (2001) also defined capital flight as residents' capital outflows, excluding recorded investment abroad [4].

There are various ways of measuring capital flight amongst which are; residual method, hot money approach, asset approach, Dooley approach, trade invoicing approach, bank deposit approach. There is no unanimity as to the appropriate the method of measuring capital flight. However, the residual method which adopts the standard balance of payments format, compares the sources of capital inflows with the use of inflows and incorporates all unrecorded private capital outflows is adopted in this study. The justification of choosing the approach lies in the fact that it acknowledges the difficulty of separating abnormal from normal capital flows. Furthermore, it has been widely used with some modifications [5], [6], [7], [8].

Boyce and Ndikumana (2002), Collier and Pattilo (2001), Mohammed and Finnoff (2004), Mohammed and Salisu (2005), and Ayadi (2008), agrees that the causes of capital flight among others are: risk perception of investors, exchange rate misalignment, financial sector constraint and repression, corruption by political leaders, macroeconomic instability, political instability and government factor, financial globalization and poor infrastructural facilities. [9], [10], [11], [12], and [13],

The various ways or channels through which capital flight is conducted is described by Gynn and Koenig (1984), Mohammed Salisu (2005) they are; foreign exchange market, parallel foreign exchange market, precious metals and collectibles and false invoicing of export and import. ${ }^{[14]},{ }^{[15]}$,

Capital flights have myriads of adverse effect on the affected country. According to Deppler and Williamson (1987), capital flight leads to a net loss investment and growth [16]. Capital flight perpetuates the debt crises not only through diversion of savings but also because retention of assets and earnings abroad erodes the domestic tax base and lead to more budget deficits that require contracting further debts to finance [17].

Capital flight can be reversed if the necessary economic policies are put in place.. According to Obadan (2004), one way of doing this is to restore confidence in the economy which would require the government to do a number of things with particular focus on the following; strengthening the financial system and improve governance, pursue sound macroeconomic policies and appropriate structure reforms, tackling the weaknesses that are causing capital flight. He further emphasized, that providing a stable financial and macroeconomic environment is crucial to reducing uncertainty and arresting capital flight. [18]

Sound macro-economic management entails having appropriate exchange and preventing the overheating of the economy, which is characterized by rising inflation, widening current account deficits, appreciating real exchange rate, rapid growing domestic credit and foreign currency debt. Prudent fiscal policy reflects low budget deficit and avoidance of destabilizing inflationary financing. The adoption of appropriate exchange and interest rate is crucial in order to reduce resource transfer abroad as well as minimize the attendant problems that such transfers create for capital scarce economies. The maintenance of competitive exchange rate is also essential for macroeconomic stability as it support the expansion of the export sector and helps to avoid balance of payment difficulties that might lead to capital fight.

Boyce (1992), postulated a direct causal link between external debt and capital flight. He further distinguishes four of such causal links; debt-driven capital flight, debt-fueled capital flight, flight-driven external borrowing and flightfueled external borrowing. [19]

Jhingan (1997), defined economic growth as a sustained and quantitative increased in per capital income, consumption, capital and volume of trade in a particular country within a period. He asserted that such growth is linked with the expansion in output only, while economic development encapsulates increase in output and change in the economic structure. Furthermore, he postulated that GNP, GNP Per capital, Welfare and social indicators are the various ways of measuring economic development. The GNP method of measuring economic growth was adopted in this study. [20] Economic literature is replete with various economic growth model amongst which are; Marx's stages of growth, the Rostow's stages of economic growth, the Marxian theory, Classical theory, Adam Smith's Theory among others. However, the adoption of any of the aforementioned theory must be done after critical analysis of the nature and structure of a particular economy.

\section{Empirical Literature}

Valerii (2009), studied and analyzed the effect of capital flight on the growth of real GDP of 136 developing countries in transition from all over the world. Secondary time series data which include private and government investments as a ratio of GDP, inflation rate, the budget deficit (including grant) as a ratio of GDP, real GDP growth, percentage change in the real effective exchange rate, population growth rate, per capital growth of GDP and other control variables which served as proxy to capital flight like growth in consumer price index (rate of inflation), growth in terms of trade were gathered. The model which was estimated to cover the period 2002 - 2006 was analyzed using the fixed and random estimation technique. In order to resolve the problem of multi-collinearity, the correlation between the proxy variables were computed. The result of this study showed that capital flight does affect economic growth negatively. Specifically, the estimation results showed that a one percentage change in capital flight will affect economic growth by 0.14 percent. [21]

Furthermore, Bakare (2011), in an attempt to identify the major sources of shock to capital flight and to grasp the full effect capital flight have on an economy introduced other macroeconomic indicators in his research besides GDP like exchange rate, inflation rate, external debt and wage rate. Secondary data were obtained from World Bank digest of statistics, Central Bank of Nigeria Statistical Bulletin and International Financial Statistics. The data been time series 
were subjected to the Johansen co-integration unit root test to avoid spurious regression result. The result of this research shows that exchange rate shock has a significant impact on capital flight, such that whenever the exchange rate deteriorates people will move their money abroad and store it in dollars. This movement is capital flight. Also, it was discovered that debt relief has a positive implication on capital flight. [22]

Otene, S. and Richard, E. (2012), the authors carried out this research as a result of the growing rate of capital flight and its devastating consequences on the Nigerian economy. Secondary data were collated from the Central Bank of Nigeria statistical bulletin for the period 1970 - 2008. In order to properly estimate the impact of capital flight on economic growth of Nigeria, Two-stage Least Square (2SLS) estimation technique was adopted. According to them, this method was employed in order to overcome the problem of multicolinearity evident in large sample, identification, simultaneity as well as likely correlation between explanatory variables and stochastic disturbance term. They admittedly, used the model in line with the work of Valerii (2009), which is an autoregressive-distributed lag model (ARDL). The Augmented Dickey-Fuller (ADF) unit root test of stationarity was done in order to avoid the phenomenon of spurious regression that makes little or no economic sense. The findings of the study showed that capital flight has a negative impact on the exchange rate and Gross Domestic Product (GDP). From the above tests; they found out that all the explanatory variables where statistically significant except interest rate differential and terms of trade which are statistically insignificant. [23]

Adaramola, A. O, Obalade, A. A (2013), conducted a research on the impact of capital flight on the Nigerian economy over the period of 30 years (1981- 2010). Secondary data were predominantly used in this study. The residual approach was employed in the computation of capital flight. Gross Domestic Product (GDP), foreign direct investment (FDI) and Current account balance were obtained while the change in external debt (DEXTD), FDI and capital flight (Kf) were computed from the Central Bank of Nigeria Statistical bulletin. The dynamic relationship between capital flight and economic growth was investigated using the Johansen cointegration test the data been time series and the avoidance of spurious regression result. From the result of the Ordinary Least Square estimation used, they found out that change in external debt (DEXTD), Current account balance (CAB) and foreign direct investment (FDI) are positively related to Gross Domestic Product (GDP). However, in contrast to other research on capital flight, their findings showed that capital flight is not statistically significant in the short run as far the GDP of Nigeria is concerned. [24]

\section{Research Method}

\subsection{Data Collection Method \& Sources}

Secondary data sourced from the Central Bank of Nigeria
Statistical Bulleting were used in this study. The dataset dwells on capital flight (KF), gross domestic product (GDP), exchange rate (ER) and External Debt (ED). Data were parameterized and analysis was conducted using global and local technique. The global technique used is ANN model. The classical techniques include multiple regression analysis of ordinary least square (OLS) estimation technique.

\subsection{Model Specification}

$\mathrm{GDP}=\mathrm{f}($ Capital Flight, Exchange Rate, External Debt $)$

$\mathrm{GDP}=\beta+\alpha_{1} \mathrm{KF}+\alpha_{2} \mathrm{ER}+\alpha_{3} \mathrm{ED}+\mathrm{e}$

Where,

$\mathrm{GDP}=$ Gross Domestic Product

$\beta=\mathrm{Y}$ intercept

$\alpha_{1}-\alpha_{3}=$ Coefficient of other variables

$\mathrm{KF}=$ Capital Flight

$\mathrm{ER}=$ Exchange Rate

$\mathrm{ED}=$ External Debt

$\mathrm{e}=$ random error

\section{Data Presentation and Analysis}

\subsection{Data Presentation}

Table 1. Gross domestic product $(G D P)$, capital flight $(K F)$, exchange rate and external debt (ED) in Nigeria (1980 - 2012).

\begin{tabular}{lllll}
\hline YEAR & GDP $\left(\mathbf{N}^{\prime} \mathbf{M}\right)$ & KF $\left(\mathbf{N}^{\prime} \mathbf{M}\right)$ & $\mathbf{E D}\left(\mathbf{N}^{\prime} \mathbf{M}\right)$ & $\mathbf{E R}(\mathbf{N} / \mathbf{S})$ \\
\hline 1980 & 31546.08 & 50.5 & 1866.8 & 0.54 \\
1981 & 205222.1 & 48.1 & 2331.2 & 0.61 \\
1982 & 199685.2 & 10.3 & 8819.4 & 0.67 \\
1983 & 185598.1 & 100.9 & 10577.7 & 0.72 \\
1984 & 183563 & 138.9 & 14808.7 & 0.76 \\
1985 & 201036.3 & 9.5 & 17300.6 & 0.89 \\
1986 & 205971.4 & 800.9 & 41452.4 & 2.02 \\
1987 & 204804.5 & 926.2 & 100789.1 & 4.02 \\
1988 & 219875.6 & 1382 & 133956.3 & 4.54 \\
1989 & 236729.6 & 3455.7 & 240393.7 & 7.39 \\
1990 & 267550 & 1247.8 & 298614.4 & 8.01 \\
1991 & 265379.1 & 969.1 & 328453.8 & 9.91 \\
1992 & 271365.5 & 2072.1 & 544264.1 & 17.3 \\
1993 & 274833.3 & 2507.2 & 633144.4 & 22.05 \\
1994 & 275450.6 & 1571.8 & 648813 & 21.89 \\
1995 & 281407.4 & 5877.5 & 716865.6 & 21.89 \\
1996 & 293745.4 & 5713.3 & 617320 & 21.89 \\
1997 & 302022.5 & 1011.7 & 595931.7 & 21.89 \\
1998 & 310890 & 5960.4 & 633017 & 21.89 \\
1999 & 312183.5 & 6149.8 & 2577374 & 102.11 \\
2000 & 329178.7 & 8528.4 & 3097384 & 102.11 \\
2001 & 356994.3 & 6960.3 & 3176291 & 112.94 \\
2002 & 433203.5 & 9225.7 & 3932885 & 126.88 \\
2003 & 477533 & 10959.1 & 4478329 & 137.22 \\
2004 & 527576 & 17955 & 4890270 & 133.5 \\
2005 & 561931.4 & 2394864 & 2695072 & 132.15 \\
2006 & 595821.6 & 2185444 & 451461.7 & 128.65 \\
2007 & 634251.1 & 2927908 & 431079.8 & 125.83 \\
2008 & 672202.6 & 2954922 & 493180.2 & 126.48 \\
2009 & 718977.3 & 5951669 & 590441.1 & 149.9 \\
2010 & 776332.2 & 3944833 & 689845.3 & 150.48 \\
2011 & 834161.9 & 4283808 & 896832.6 & 158.21 \\
2012 & 902794 & 4726770 & 1026904 & 159.39 \\
\hline & & & & \\
\hline
\end{tabular}

Source: Central Bank of Nigeria $(C B N)$ Statistical Bulletin. 


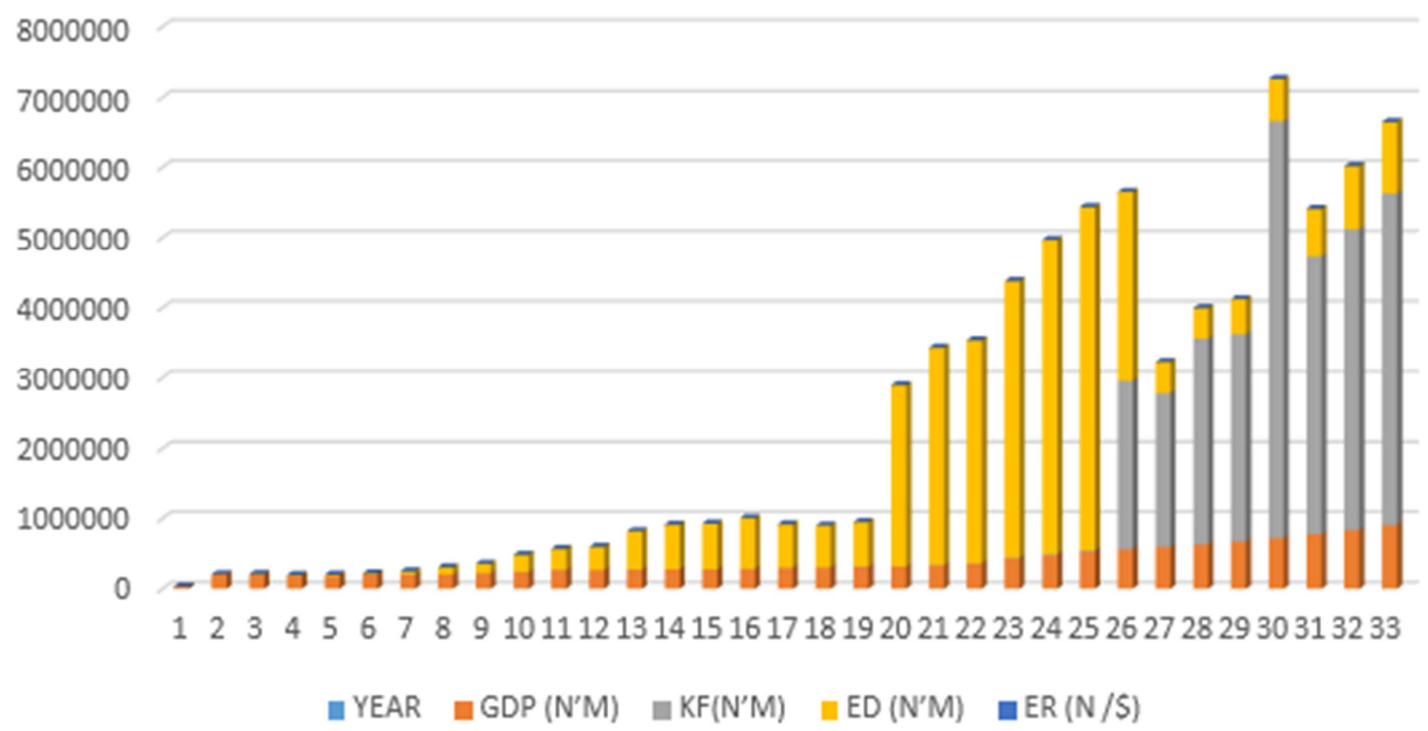

Figure 1. Chart Showing the Relationship between Gross domestic product (GDP), capital flight (KF), exchange rate and external debt (ED) in Nigeria (1980 - 2012).

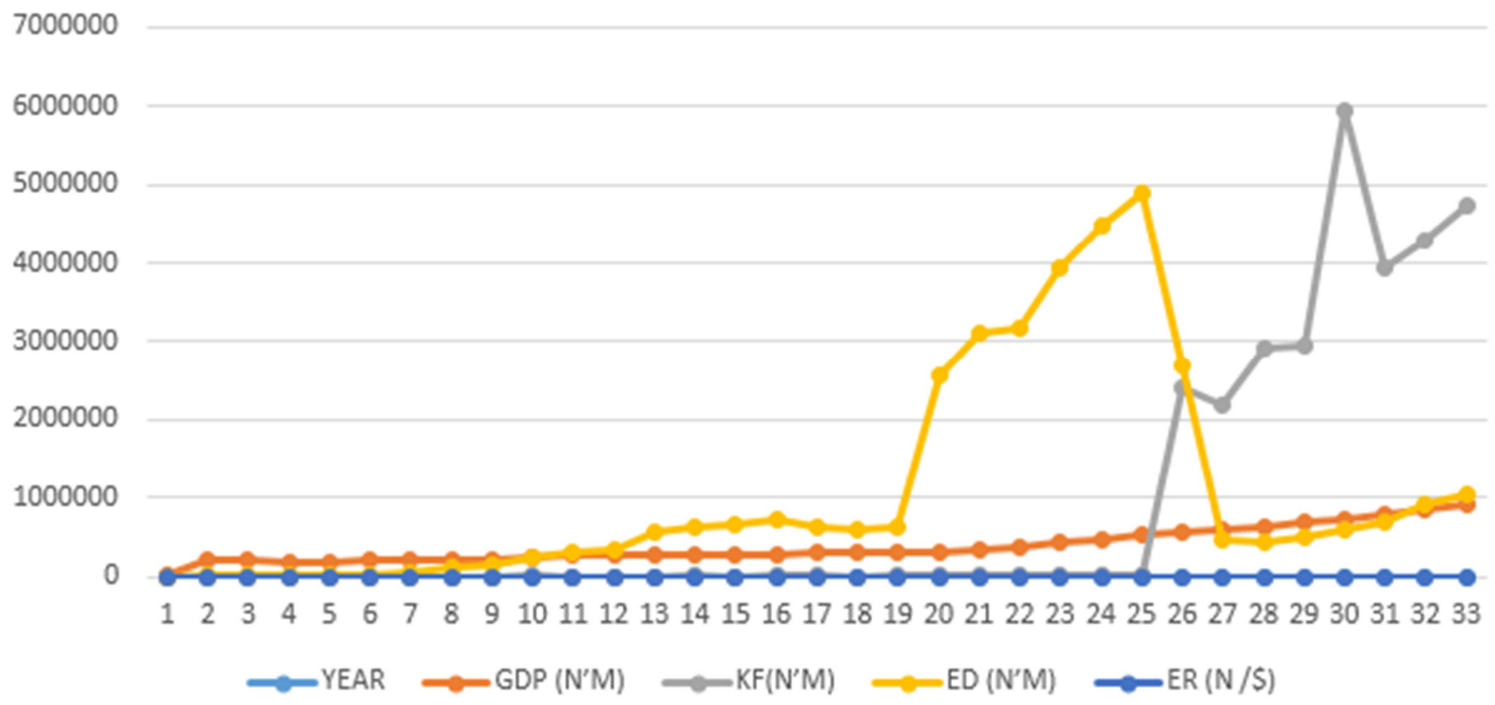

Figure 2. Chart Showing Trend Over Time in Years between Gross domestic product (GDP), capital flight (KF), exchange rate and external debt (ED) in Nigeria $(1980-2012)$.

\subsection{Data Analysis}

Using the popularly known and widely used econometrics computer software e-view, the data in table were analyzed as follows:

Table 2. Short Run Analysis.

\begin{tabular}{lllll}
\hline Variable & Coefficient & Std. Error & t-Statistic & Prob. \\
\hline $\mathrm{C}$ & 207431.1 & 15214.57 & 13.63371 & 0.0000 \\
$\mathrm{KF}$ & 0.047382 & 0.021146 & 2.240739 & 0.0329 \\
$\mathrm{ED}$ & -0.018831 & 0.022591 & -0.833562 & 0.4113 \\
$\mathrm{ER}$ & 2441.564 & 716.9282 & 3.405591 & 0.0020 \\
R-squared & 0.929108 & Mean dependent var & 380297.5 \\
Adjusted R-squared & 0.921774 & S. D. dependent var & 217278.8 \\
Log likelihood & -408.1833 & F-statistic & 126.6906 \\
Durbin-Watson stat & 1.219182 & Prob (F-statistic) & 0.000000 \\
\hline
\end{tabular}

Source: Computed Result from (E-View 3.1)
The short run result as reported in table 2 above shows that the coefficient of determination- $\mathrm{R}^{2}$ is 0.929 , indicating that the explanatory power of the model estimated is 93 percent. Therefore the systematic variation in GDP explained by capital flight, external debt and exchange rate is 93 percent. The coefficient of capital flight (KF) appeared with the wrong sign (positive) but statistically significant. Meanwhile, the coefficient of external debt (ED) variable appeared with the right sign (negative) but statistically not significant at 5 percent level. This conforms to the apriori expectation. But external debt does not impact on economic growth during the period of study. Also the result shows that exchange rate appeared with the right sign and equally impact on economic growth in Nigeria during the period of study. The entire regression model is significant given that the f-value of 126.69 which is greater than the f-table of 2.97. Therefore, 
we reject the null hypothesis and accept the alternative hypothesis which states that there is a significant relationship between capital flight and economic growth in Nigeria. The Durbin Watson value of 1.219 shows the presence of serial autocorrelation in the model.

Based on the analysis of the short run above, the regression result is spurious given a high $\mathrm{R}^{2}$ of 93 percent, the presence of autocorrelation. These may attributed to nonstationarity of time series data that are used for the study. Therefore, there is need to carry second order test to confirm the long run analysis.

\section{Long Run Analysis}

Due to the spurious nature of short run analysis, a stationary test become necessary to stabilize the data. This will be followed by the Johansen co integration test and the error correction mechanism to establish the long run equilibrium relationship among the variables.

Unit Root Test

Here, we proceed by conducting the unit root test for the stationary of the variables. The study employs the Augmented Dickey Fuller (ADF) tests.

Table 3. Unit Root Stationary Test (1980-2012).

\begin{tabular}{llllll}
\hline \multirow{2}{*}{ Variables } & ADF Test & Critical Value & & Order of integration \\
\cline { 2 - 6 } & & $\mathbf{1 \%}$ critical value & $\mathbf{5 \%}$ Critical value & $\mathbf{1 0 \%}$ critical value & \\
\hline D (GDP) & 6.379615 & -3.6576 & -2.9591 & -2.6181 & $(0)=$ At Level \\
D (KF) & -4.289290 & -3.6661 & -2.9627 & -2.6200 & $(1)=1^{\text {St }}$ Diff. \\
D (ED) & -3.83579 & -3.6661 & -2.9627 & -2.6200 & $(1)=1^{\text {St }}$ Diff. \\
D (ER) & -3.677299 & -3.6661 & -2.9627 & -2.6200 & $(1)=1^{\text {St }}$ Diff. \\
\hline
\end{tabular}

Source: computed Result from (E-view 3.1).

The unit root test in table 3 above show that at various levels of significance $(1 \%, 5 \%$ and $10 \%)$, the variables were stationary. From the result only GDP was integrated of order zero (at level), while the other variables (capital flight, external debt and exchange rate) were integrated of order one (first difference), therefore all the time series in this study are stationary.
A. Co-integration Test

Co-integration is conducted based on the test proposed by Johansen. According to Iyoha and Ekanem, (2002) Cointegration deals with the methodology of modeling nonstationary time series variables. [27] The Johansen cointegration test is presented in table 4 below.

Table 4. Test for Co-integration.

\begin{tabular}{lllll}
\hline Eigen value & Likelihood Ratio & $\mathbf{5 \%}$ critical value & $\mathbf{1 \%}$ critical value & Hypothesized No. of CE (s) \\
\hline 0.897012 & 135.8019 & 47.21 & 54.46 & None $* *$ \\
0.832338 & 69.88071 & 29.68 & 35.65 & At most $1 * *$ \\
0.383945 & 18.09233 & 15.41 & 20.04 & At most $2 *$ \\
0.130168 & 4.044187 & 3.76 & 6.65 & At most $3 *$ \\
\hline
\end{tabular}

Source: Computed Result Using (E-Views 3.1).

Table 4 above, it shows that there are four co- integrating equations at $5 \%$ level of significance. This is strong evidence from the unit root test conducted, where we observed that all the variables except GDP are stationary at order one. Given that there exists co-integrating equations, the requirement for fitting in an error correction model is satisfied.

B. Error Correction Model (ECM)

Error correction model (ECM) is a means of integrating the short-run behaviour of an economic variable with its long-run behavior [28]. In order to capture the short-run deviations that might have occurred within the period of the study. This is done by following the general-to-specific rule. Specifically, we start by specifying the over-parametized preferred parsimonious short-run dynamic result. The estimated result of the parsimonious ECM obtained is showed below:
Table 5. Parsimonious Error Correction Model.

\begin{tabular}{lllll}
\hline Variable & Coefficient & Std. Error & t-Statistic & Prob. \\
\hline C & 4891.112 & 4808.392 & 1.017203 & 0.3206 \\
D (GDP (-1)) & 0.655322 & 0.213403 & 3.070820 & 0.0058 \\
D (GDP (-2)) & 0.208599 & 0.224262 & 0.930158 & 0.3629 \\
D (GDP (-3)) & 0.016671 & 0.092652 & 0.179937 & 0.8589 \\
D (KF (-1)) & -0.000288 & 0.004144 & -0.069496 & 0.9453 \\
D (ED (-1)) & -0.001416 & 0.005881 & -0.240760 & 0.8121 \\
D (ER (-1)) & 204.7808 & 268.5269 & 0.762608 & 0.4542 \\
E CM (-1) & -12688.22 & 22154.86 & -0.572706 & 0.5729 \\
R-squared & 0.638771 & Mean dependent var & 24730.89 \\
Adjusted R-squared & 0.518361 & S. D. dependent var & 22808.77 \\
Log likelihood & -316.8880 & F-statistic & & 5.304977 \\
Durbin-Watson stat & 1.974495 & Prob (F-statistic) & 0.001321 \\
\hline
\end{tabular}

Source: Computed Result Using (E-Views 3.1). 


\section{Discussion of Findings}

Figure three demonstrates a graphical view of result obtained by training the network. The result of Nftool reveals a good and perfect forecast of the network. The straight lines (Figure 3) demonstrate the linear connections which exist between the output response of the dataset used in this study. The correlation coefficients (R) between the definite value and the forecasted values are found to be unity (1) for training, 0.94011 for validation, 0.96124 for testing and 0.62257 for performance. Also, the goodness of fit of this network as indicated by the average determination coefficient $\left(\mathrm{R}^{2}=0.665\right)$ implies that $66.5 \%$. The value obtained is good and demonstrate a good prediction of the network.

Table 5, shows that the coefficient of ECM appeared with the right sign but statistically not significant at the 5\% level. This will help to correct any deviation from long-run equilibrium. Moreover, the Durbin Watson value of 1.97 is very close to 2.0 , therefore this suggests a lesser level of autocorrelation as compared to the short run linear result. The R-squared of 0.638 shows that 64 percent of the systematic variation in economic growth is explained by the ECM. This shows a good fit. The F-statistic of 5.30 is significant at the $5 \%$ level. Therefore, we reject the null hypothesis and conclude that there is a significant relationship between capital flight and economic growth in Nigeria during the period of study.

More importantly is the coefficient of capital flight (KF). The lag one forms of the capital flight variable (KF) is negatively signed. This conforms to apriori expectation. What this suggests is that capital flight alone will not reduce economic growth (proxied by real gross domestic product).

Moreover, the lag one forms of the two checks variables (ED and ER) were rightly signed. All these conform to apriori expectation. But for the three periods, the independent variables were not statistically significant at 5 percent level.
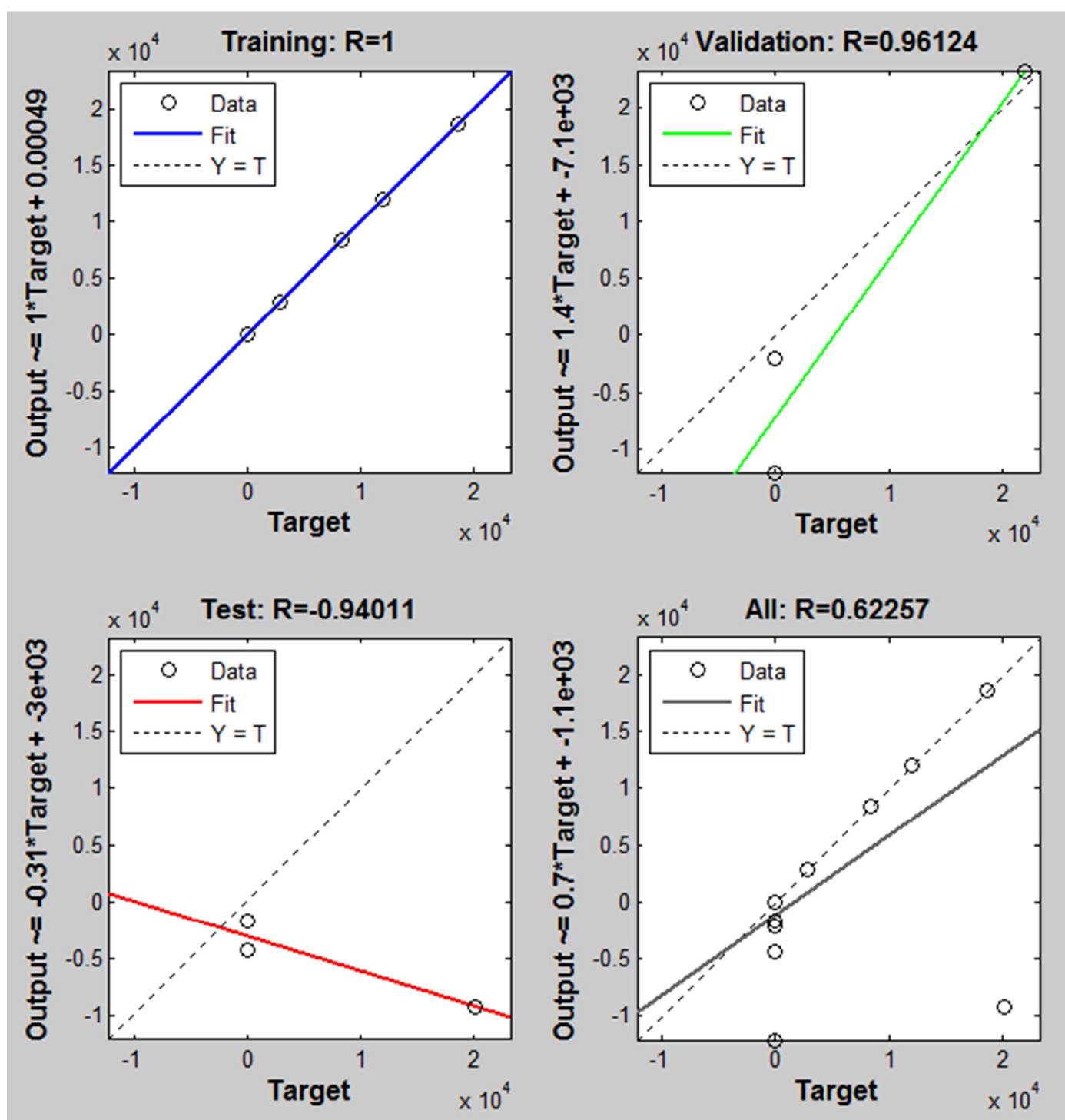

Figure 3. Training, Testing and Validation of Dataset Using Artificial Neural Network A. 


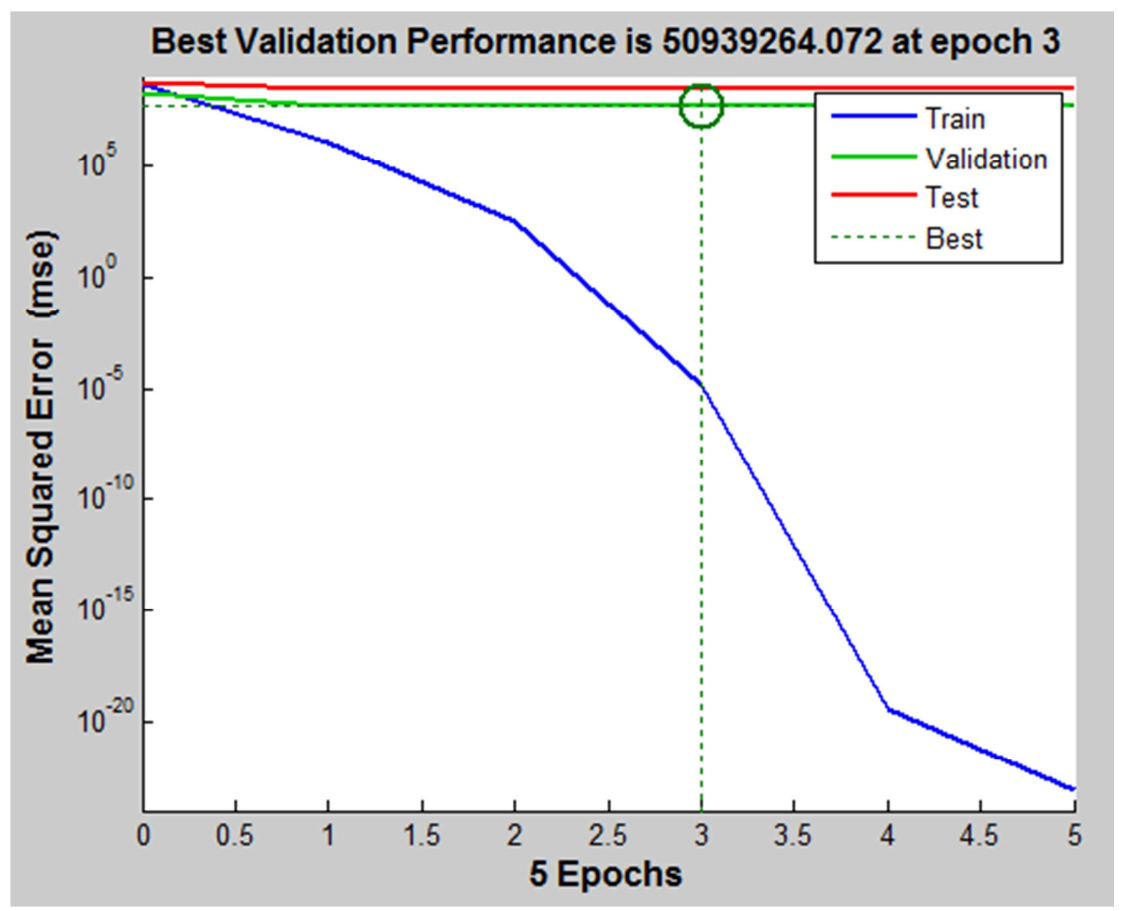

Figure 4. Demonstrate the Best Validation Performance.

\section{Recommendations}

The long run analysis shows that there is a negative relationship between capital flight and gross domestic product in Nigeria during the period under study. Therefore, government should check the volume of capital that is flown out of the country through appropriate institutions. Furthermore, there should be restriction on external borrowing tendencies of different levels of government and agencies as well as private sector organizations. External borrowings should be an exercise of last resort and should be exclusive responsibility of the Federal Government. To achieve long-term solution to the problem of external debts burden, there should be the promotion of the country's export trade and drastic production in the merchandise imports.

\section{Conclusion}

This study employed an analytical methodology to examine the impact of capital flight on economic growth in Nigeria. The concept, causes, channels and effect of capital flight on the Nigeria economy was reviewed. From the long run analysis of the regression results, the coefficient of capital flight (KF) was negatively signed which is in tandem with economic theory. This means that capital flight has a negative impact on economic growth.

Furthermore, one of the check variables employed in this study is the exchange rate, reason be that it is often found to be an important variable in the study of capital flight and its determinants [29]. The regression result shows that the coefficient of the exchange rate is positive which conforms to apriori expectations. By implication, an appreciation of the exchange rate of the naira leads to increase in domestic production, increase in exportation; decrease in importation an increase in foreign reserve which in turn results to economic growth.

Finally, in light of the apriori relationship and multiplier effects on capital flight and economic growth, external debt variable was chosen as one of the check variables in this study. Research has shown that countries that exhibit the greatest capital flight are also most highly indebted. This finding is consistent with the hypothesis that capital flight and external debt are closely "inter twin" [30]. From the regression result, the coefficient lag one forms of the external debt variable (ED) is negatively signed. This conforms to apriori expectation. What this suggests is that an increase in capital flight will exacerbate external debt which will consequently reduce economic growth in Nigeria

\section{References}

[1] Onwioduokit E. A. (2007), "Capital Flight from Nigeria: An Empirical Re-Examination Accra, Ghana: West African Monetary Institute.

[2] World Bank. (1985) Case study: Mexico. In D. R. Lessard \& J. Williamson, (Ed.), Capital flight and third World debt. Washington, D. C.: Institute for International Economics.

[3] Cooper, H. W., \& Hardt, J. P. (2000). Russian Capital Flight, Economic Reforms, and U.S Interests. Congressional Research Service (CRS), Report for congress.

[4] Boyce, J. K., \& Ndukumana, L. (2001). Is Africa a Net Creditor? New Estimates of Capital Flight from Severely Indebted Sub-Saharan African Countries. Journal of Development Studies, 38 (2) 27-56.

[5] World Bank (1995). 
[6] Erbe, S. (1985) "The Flight of Capital from Developing Countries", Intereconomics (November/December).

[7] Morgan G. T. C (1986): 'LDCs Capital Flight, World Financial Market”, (March).

[8] Cline, William R., "Discussion" (of Chapter 3), in Donald R. Lessard and John Williamson, eds., Capital Flight and Third World Debt, Washington, D. C., Institute for International Economics, 1987.

[9] Boyce, J. K., \& Ndukumana, L. (2001). Is Africa a Net Creditor? New Estimates of Capital Flight from Severely Indebted Sub-Saharan African Countries. Journal of Development Studies, 38 (2) 27-56.

[10] Collier, P., Hoefler. A \& Patillo C. (2001). Flight Capital as a Portfolio Choice, World Bank Economic Review. Vol 15/1.

[11] Mohammed S. and Finoff K. (2004). 'Capital flight from South Africa, 1980-2000. African.

[12] Development and Poverty Reduction, Forum Paper.

[13] Salisu, M. (2005). The Role of Capital Flight and remittances in Current Account Sustainability in Sub-Saharan Africa. Development Research Department, African Development Bank.

[14] Ayadi. (2008). Econometric Analysis of Capital Flight in Developing Countries. 8th Global Conference of Economics, (p. 32 (8)). Abuja.

[15] L. Glynn, P. Koenig: The Capital Flight Crisis, in: Institutional Investor, November 1984.

[16] Salisu, M. (2005). The Role of Capital Flight and remittances in Current Account Sustainability in Sub-Saharan Africa. Development Research Department, African Development Bank.

[17] Deppler, M., \& Williamson, M. (1987). Capital Flight: Concept, Measurement and Issues. Washington: International Monetary Fund.

[18] Chukwuma, A. (2010). Domestic Macroeconomic Policies and Capital Flight from Nigeria: Evidence from A Macro- econometrics Model. Economic and Financial Review, p. volume $48 / 3$.

[19] Obadan, M. I. (2004). The Economics of Development And Planning. India. Vrinda Publication Ltd.

[20] Boyce, J. K., \& Ndukumana, L. (2001). Is Africa a Net Creditor? New Estimates of Capital Flight from Severely Indebted Sub-Saharan African Countries. Journal of Development Studies, 38 (2) 27-56.

[21] Jingan, M. L (1997). Applied Econometrics. Benin City. Mindex Publishing.

[22] [24). Valeriia, G. (2009). The Impact of Capital Flight on Economic Growth. Russia; Kyive School of Economics.

[23] Bakare, A. S. (2011). The Determinants and Roles of Capital Flight in the Growth of Process of Nigerian Economy: Vector Autoregressive Model Approach. British Journal of Management and Economics, 1 (2), 100-133.

[24] Otene, S. and Richard, E. (2012. Capital Flight and Nigeria, s Economy. Journal of Research In National Development. 10 (2).

[25] Adaramola, A. \& Obalade, A. A. (2013). Does Capital Flight Have a Force to Bear on Nigeria Economic Growth. International Journal of Developing Societies, vol 2 (2).

[26] Central Bank of Nigeria (CBN) Statistical Bulletin (2012).

[27] Iyoha, M. A (2004). Applied Econometrics. Benin City. Mindex Publishing.

[28] Gujarat \& Sageetha (2007), Basic Econometrics. India. Tata Mcgraw Hill Publishing Company.

[29] Akani, W. H. (2013). Analysis of the Effects of Capital Flight on Economic Growth: Evidence from Nigerian Economy. European Journal on Business and Management, vol 5, No. 17.

[30] Boyce, J. K., \& Ndukumana, L. (2001). Is Africa a Net Creditor? New Estimates of Capital Flight from Severely Indebted Sub-Saharan African Countries. Journal of Development Studies, 38 (2) 27-56. 